\title{
Insight
}

ChINA \& WTO ReV. 2019:1; 215-218

http://dx.doi.org/10.14330/cwr.2019.5.1.12

pISSN 2383-8221 • elSSN 2384-4388

\section{Canada's Stance on Huawei CFO's Arrest: How Highly Disputed Case Will Unfold?}

\author{
Ji Hee Suh* \\ Canadian Rapporteur
}

The arrest of Meng Wanzhou, CFO of international telecom giant Huawei Technologies, have fired up political and diplomatic commotions around the world. Meng's arrest in Vancouver based on several indictment charges accused by the US government against Meng particularly situated Canada in a precarious position of standing strong as an ally of the US, but also avoiding needless enragement of China. Because the US filed a formal extradition request to Canada, Canada's federal Minister of Justice has to determine whether Meng's extradition hearing will take place, by examining legal prongs under the US-Canada Extradition Treaty. The international communities will be watching closely of this contentious extradition case that will certainly have huge implications on diplomatic, economic and political relationships between the Western world and China.

Keywords: Huawei, Meng Wanzhou, US-Canada Extradition Treaty, China

With the trade war between the US and China raging on for months, the latest news that is gaining international political commotion is arrest of Wanzhou Meng, the Chief Financial Officer of Chinese telecom giant Huawei Technologies and the daughter of Huawei's founder, Ren Zhengfei. On December 1, 2018, Meng was taken into custody in Vancouver International Airport, Canada, for extradition to the US while en route from Hong Kong to Mexico, accused of thirteen indictment charges by the US government including violating the US sanctions on Iran. Since

* In-House Attorney at Hanmi Pharmaceutical / Hanmi Science Co. Ltd; Attorney-at-Law (California \& Wisconsin Bar). B.Sc. (UBC), J.D. (Wisconsin). ORCID: http://orcid.org/0000-00033761-9838. The author may be contacted at: suh23@wisc.edu/Address: Samsung Tower Palace Suite B-dong, Unjuro 30 gil 56, Gangnam-Gu, Seoul 06294 Korea. 
Meng's arrest, political and diplomatic tensions have fired up between China and Canada, effectively positioning Canada right in the centre of the US-China dispute.

So, why are Meng's arrest and accusation against Huawei escalating into a heated international commotion? Huawei, one of the largest private telecommunication companies in China, is also one of the largest telecommunications equipment manufacturers in the world. In Canada alone, Huawei committed about CAD 50 million to ten leading Canadian universities in order to fund 5G technology on the past decade, which Huawei used as the basis for hundreds of patent filings. ${ }^{1}$ The Company's ever growing $5 \mathrm{G}$ telecommunications infrastructure soon became monitoring target for the US intelligent agencies. ${ }^{2}$ In fact, chiefs of six US intelligence agencies and three former heads of Canada's spy services are warning the Trudeau government that Huawei is fast becoming cyber-intelligence threats, so that its $5 \mathrm{G}$ technology could be used to conducting remote spying, stealing information, or even shutting down systems. ${ }^{3}$

In addition to this upcoming development of cybersecurity threats, the US Department of Justice is also charging Meng as part of an alleged conspiracy by Huawei to sidestepping the US sanctions on Iran and stealing trade secrets. ${ }^{4}$ Meng allegedly deceived a US bank for the US dollar and Euro clearing, by misrepresenting ownership and control of Huawei's subsidiary in Iran, Skycom. ${ }^{5}$ Attorney General Matthew Whitaker stated that Meng and Huawei employees falsely led the banking partners to believe that Huawei sold off its ownership interest in Skycom, and in turn, facilitating more than USD 100 million worth of Skycom transactions through the US in four years. ${ }^{6}$ Meng is also accused of lying to Congress and obstructing justice, in addition to violating Iranian sanction, of which includes destroying evidence and moving potential witness back to China out of the US prosecution's reach.

With the US filing a formal extradition request for Meng to Canada's Department of Justice, the whole situation puts Canada in a precarious position of not only standing strong as an ally of the US, but also avoiding needless enragement of one of Canada's biggest trading partners - China. The next step for Canada will be determining if there is sufficient evidence to support extradition of Meng under the US-Canada Extradition Treaty. Once Canada's federal Minister of Justice decides an extradition hearing can be heard, Meng will stand before a 
Superior Court judge, who will then determine not of Meng's innocence or guilt, but of evidence provided by the US is sufficient to justify extradition itself. ${ }^{8}$

There are a number of preliminary legal requirements that must be satisfied for extradition to occur. The first requirement to be met is 'double criminality,' which means the crime for which Meng is charged against must be also amount to a crime in Canada for extradition to be completed. ${ }^{9}$ Meng's charges, which are violation against Iranian sanction and conspiracy to defraud, are known to Canadian law under the Special Economic Measure Act. ${ }^{10}$ It is an offense in Canada to have economic dealing with foreign states against which the government has issued sanctions, and Iran is one of the listed countries. ${ }^{11}$

Yet, even though the Canadian law runs parallel to the relevant US laws, Canadian law differs from its southern counterpart in that the Special Economic Measures Act does not apply against foreign nationals who acted outside of Canada. ${ }^{12}$ On the other hand, the US is pursuing Meng for conduct that occurred outside of the US jurisdiction. Professor Robert J. Currie at Dalhousie University's Schulich School of Law states that whether extradition is available under these kinds of differences in territorial jurisdiction will be made by federal Minister of Justice, who will take into account of a complex set of factors, including political and diplomatic functions. Such functions will include the fact that the alleged bank and wire fraud involved the US dollar transaction that passed through the US, exposing America banks to penalties for unknowingly violating the US sanction law. ${ }^{13}$

The second legal requirement under the US-Canada Extradition Treaty is that the extradition should not be politically motivated or oppressive. ${ }^{14}$ Canada may reject the extradition request, if federal Minister of Justice concludes that the US charges are politically motivated. The US President Donald Trump asserted less than two weeks after Meng's arrest that: "If I think it's good for what will be certainly be the largest trade deal ever made [with China], I would certainly intervene [Meng's case] if I thought necessary." the US President to intervene the case in order to secure a better trade deal with China may fail to satisfy the non-political motivation prong in the US-Canada Extradition Treaty. In such case, Meng will be discharged.

Because the US filed a formal extradition request on January 28, Canada would have 30 day window to determine whether the extradition hearing of 
Meng will take place. The international communities will be watching closely of this contentious extradition case that will certainly have huge implications on diplomatic, economic and political relationships between the Western world and China.

\section{REFERENCES}

1. S. Chase, US Lawmakers Warn Canada about Chinese Telecom Giant Huawei, Globe \& MAIL, June 18, 2018, available at https://www.theglobeandmail.com/politics/article-uslawmakers-warn-canada-about-chinese-telecom-giant-huawei (last visited on Feb. 10, 2019).

2. Id.

3. Id.

4. A. Russell, US Hits Huawei and CFO Meng with 23 Criminal Charges. Here's What You Need to Know, Global News, Jan. 29, 2018, available at https:/globalnews.ca/news/4901371/ huawei-criminal-charges-stealing-secrets-evading-sanctions (last visited on Feb. 10, 2019).

5. US Charges Huawei, Proceeding with Meng Extradition from Canada, Global News, Jan. 28, 2019, available at https://globalnews.ca/news/4898558/us-china-huawei-charges (last visited on Feb. 10, 2019).

6. Supra note 4.

7. Id.

8. D. Cochrane, Canada Had No Choice But to Arrest Huawei Executive at Washington's Request: Expert, CBC NEws, Dec. 7, 2018, available at https:/www.cbc.ca/news/politics/ meng-huawei-extradition-1.4937146 (last visited on Feb. 10, 2019).

9. Treaty of Extradition, US-Can., art II, Dec. 3, 1971, CTS 1976 No.3. For details, see R. Currie, On the Huwawei Extradition Case, Canada's Legal System Better Stand Up To Scrutiny, Globe \& MaIL, Dec. 9, 2018, available at https://www.theglobeandmail.com/ opinion/article-on-the-huawei-extradition-case-canadas-legal-system-better-stand-up (last visited on Feb. 10, 2019).

10. Currie, id.

11. Id.

12. Id.

13. Huawei Executive's Extradition to US far from Slam Dunk, says Lawyers, Experts, VANCOUvER Sun, Feb. 5, 2019, available at https://vancouversun.com/news/local-news/huawei-executivesextradition-to-u-s-far-from-slam-dunk-say-lawyers-experts (last visited on Feb. 10, 2019).

14. Treaty of Extradition art. IV.

15. Supra note 13. 